\title{
Application of Thermosonication in Red Pitaya Juice Processing: Impacts on Native Microbiota and Quality Properties during Storage
}

\author{
Wenxian Zhu ${ }^{1}$, Yana $\mathrm{Ai}^{1}$, Fang Fang ${ }^{2}$ (D) and Hongmei Liao ${ }^{1, *(\mathbb{D})}$ \\ 1 School of Food Science and Technology, Collaborative Innovation Center of Food Safety and Quality Control \\ in Jiangsu Province, Jiangnan University, Wuxi 214122, China; zwx15761636900@163.com (W.Z.); \\ 6190112001@stu.jiangnan.edu.cn (Y.A.) \\ 2 Whistler Center for Carbohydrate Research, Department of Food Science, Purdue University, \\ West Lafayette, IN 47906, USA; ffang@purdue.edu \\ * Correspondence: hmeiliao@jiangnan.edu.cn
}

check for updates

Citation: Zhu, W.; Ai, Y.; Fang, F.;

Liao, H. Application of

Thermosonication in Red Pitaya Juice Processing: Impacts on Native Microbiota and Quality Properties during Storage. Foods 2021, 10, 1041. https://doi.org/10.3390/foods10051041

Academic Editor: Victor Rodov

Received: 2 April 2021

Accepted: 8 May 2021

Published: 10 May 2021

Publisher's Note: MDPI stays neutral with regard to jurisdictional claims in published maps and institutional affiliations.

Copyright: (c) 2021 by the authors. Licensee MDPI, Basel, Switzerland. This article is an open access article distributed under the terms and conditions of the Creative Commons Attribution (CC BY) license (https:// creativecommons.org/licenses/by/ $4.0 /)$.

\begin{abstract}
The effects of thermosonication (TS) on microbial safety and quality of red pitaya juice during storage were assessed in this study. Freshly prepared red pitaya juices were thermosonicated at $475 \mathrm{~W}$ and $56^{\circ} \mathrm{C}$ for $20 \mathrm{~min}$. Upon TS processing, native microbiota including aerobic bacteria, yeasts, and molds reduced to less than $10 \mathrm{CFU} / \mathrm{mL}$. Their growth during storage were slow and equal to thermal-processed $\left(83^{\circ} \mathrm{C}, 1.5 \mathrm{~min}\right)$ samples. During storage at $4{ }^{\circ} \mathrm{C}$ for 28 days, soluble solid content, $\mathrm{pH}$, activities of polyphenol oxidase and peroxidase, and browning degree remained unchanged. A visible color decay was observed in TS-processed samples at day 10, mainly resulting from decomposition of betacyanins and the growth of residual native microbiota. Compared to thermal-treated juices, better color retention was obtained by TS treatment. Therefore, TS is a promising alternative technology of thermal methods of juice processing, with equal shelf life and better quality retention effects.
\end{abstract}

Keywords: native microbiota; physico-chemical quality; red pitaya juice; storage; thermosonication

\section{Introduction}

Fruit juice is popular all around the world as a good source of sugars, vitamins, polyphenols, flavonoids, and minerals. Processing fresh fruits to juices normally involves thermal treatments to inactivate microorganisms and enzymes, which avoid putrefying of fresh fruit during transportation and storage to ensure food safety and extend shelf life of fruit juice products [1]. However, high temperature treatment usually causes undesirable changes in sensory attributes, including texture, flavor, color, smell, and losses in nutritional qualities [2]. As consumers' preference shifts towards high-quality and less or non-processed fruit juices, developing novel technologies as an alternative of thermal processing is of growing interest, especially for fruit juice processing.

Red pitaya is a kind of tropical fruit with a bright purple-red color, which is one of the attributes to attract consumers and derives from betacyanins, an antioxidant with known health benefits [3]. Recently, it had been reported that pitaya fruit were processed into juice, puree, and natural pigment extractive [4-6]. Proper processing of this fruit overcomes its seasonal and regional characteristics and produces high-quality products that is always in demand. Red pitaya juice attracts increasing attention due to its nutritional functionalities, special purple-red color, and soft, bright, and fresh taste. To retain the desirable characteristics of red pitaya during juice processing and storage, well-controlled processing and storage conditions should be investigated. More exactly, its characteristics of rich in natural soluble solid content (SSC) might result in that juice is susceptible to microbial spoilage and easy to decay, and its color is sensitive to heat and light. Those should be considered primarily during processing and following shelf-life estimation. 
Recently, some non-thermal technologies or their combination forms have been applied in pitaya juice processing, including UV-C irradiation and ozone-HHP $[4,7,8]$. For instance, pitaya juice subjected to ozone for $7 \mathrm{~min}$ and followed by high hydrostatic pressure (HHP) at $316 \mathrm{MPa}$ for $5 \mathrm{~min}$ shows negligible color change, highest sensory preference (79\%), and non-detectable levels of native microbiota after stored for 35 days at $5 \pm 2{ }^{\circ} \mathrm{C}$ [4]. However, an unstable shelf life of juice that is caused by endogenous enzymes due to relatively low inactivation efficiency of these non-thermal technologies and high investment or operational costs would obstacle their industrial application for red pitaya juice processing.

Thermosonication (TS) is an energy-efficient technology by combining ultrasonication with moderate heat. The physicochemical and thermal effects formed by acoustic cavitation and ultrasound waves result in the inactivation of microorganisms and/or endogenous enzymes in food [9]. Recently, it attracted growing research interests. It has been reported that enzymes in apple juice, including polyphenol oxidase, peroxidase, and pectin methylesterase, were effectively inactivated by this technology [9]. Besides that, yeast and molds (Y\&M) reduced to a level below the detection limit of plate counting assay in the same study. Compared to high temperature thermal treatment, higher contents of natural pigments, polyphenol, and flavonoids (e.g., anthocyanin) were retained in carrot juice and bayberry juice after TS treatment $[10,11]$. During storage at $4{ }^{\circ} \mathrm{C}$, TS-treated juices (e.g., carrot and orange juices) had a slow growth rate of total mesophiles and Y\&M [12,13], suggesting its potential for red pitaya juice processing. However, there is a knowledge gap on tracing quality index, nutritive value, and microbial safety of TS-processed juices during storage, they are the basic guarantee for evaluating and predicting their shelf lives.

Our previous study revealed that TS preserves the color of red pitaya juice better than thermal treatment, but still results in degradation and isomerization of betacyanins, as well as non-enzymatic browning [14]. Color is an important attribute relating with the visual appeal and quality of fruit juice [15]. Generally, color changes of fruit juice are mainly related to enzymatic browning of phenolic compounds, degradation of pigments, and non-enzymatic browning during or after processing [16]. Nevertheless, no literature has reported physico-chemical and microbial qualities of clear red pitaya juice treated by TS during storage. It is important and the premise of its application in industrial scale. Therefore, the objectives of this study were to evaluate the microbial safety and quality index of TS-processed clear red pitaya juice during storage, and to assess the possibility of TS as an alternative technology of thermal processing.

\section{Material and Methods}

\subsection{Preparation of Clear Red Pitaya Juice}

Preparation of clear juice of red pitaya fruit (Hylocereus polyrhizus) followed the method as described by Liao et al. [14]. Two batches of clear red pitaya juice, $12 \mathrm{~L}$ of each batch, with initial soluble solid content of $12.9 \pm 0.1^{\circ}$ Brix and $\mathrm{pH}=4.77 \pm 0.01$, were prepared in December 2018 and June 2019, respectively. Obtained juice was stored in sterilized glass bottles at $4{ }^{\circ} \mathrm{C}$ until further treatments.

\subsection{Experimental Design}

The above-mentioned two batches of juice were divided into four groups randomly, to be treated by TS, ultrasonication (US), and thermal processing, with a group untreated as control samples (Figure 1). The untreated and treated red pitaya juice samples in glass bottles (50 mL/bottle) were stored at $4 \pm 1{ }^{\circ} \mathrm{C}$ and $25 \pm 1{ }^{\circ} \mathrm{C}$, respectively; they were sampled every other day at $25^{\circ} \mathrm{C}$, and were sampled on days $2,4,7,10,15,20,25$ and 28 during storage at $4{ }^{\circ} \mathrm{C}$. The microbial and quality index of those samples were analyzed immediately. All treatments were repeated at least twice. The analytical measurements on pitaya juices for each treatment were performed in triplicate. 


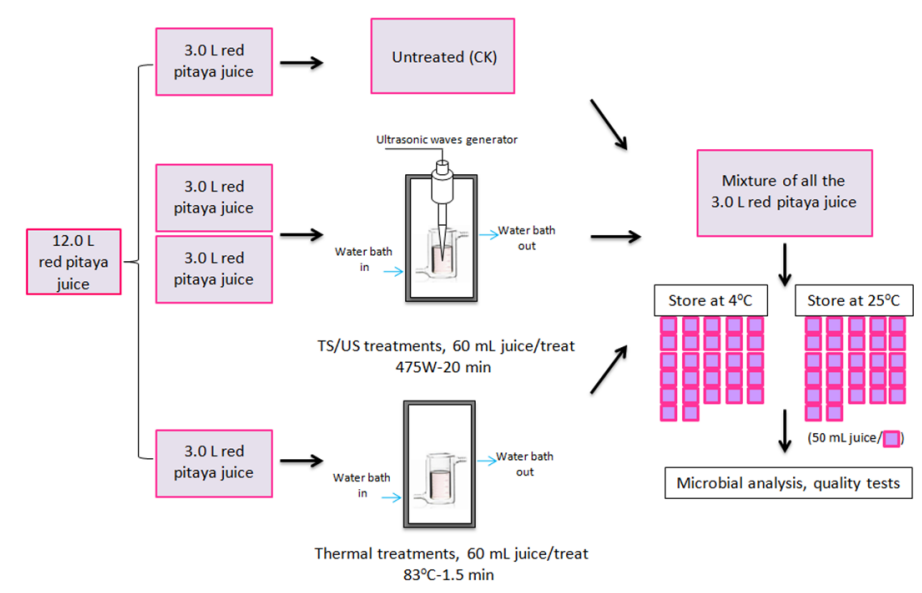

Figure 1. A schema of the experimental design for each batch.

\subsection{Thermosonication, Ultrasonication, and Thermal Treatments}

As described in Liao et al. [17], TS treatments were conducted using an ultrasonic processor with $10 \mathrm{~mm}$ probe (Scientz-IID, Ningbo Scientz Biotechnology Co., Ltd., Zhejiang, China). Each $60 \mathrm{~mL}$ clear red pitaya juice in $150 \mathrm{~mL}$ double-walled glass vessel was adjusted to $56{ }^{\circ} \mathrm{C}$ using a thermostatically controlled water bath (DC0506, Hengping Instrument \& Meter Factory, Shanghai, China). The input power was $475 \mathrm{~W}$, the pulse time interval was $3 \mathrm{~s}$, and the duration was $20 \mathrm{~min}$. US treatments were conducted using the above-mentioned ultrasonic processor, with samples' temperature controlled at $10 \pm 1{ }^{\circ} \mathrm{C}$. Thermal treatments were conducted as following: $60 \mathrm{~mL}$ juice in a $150 \mathrm{~mL}$ double-walled glass vessel was connected with a temperature-controlled water bath and held for $1.5 \mathrm{~min}$ since its center temperature reached $83^{\circ} \mathrm{C}$. Samples were incubated in an ice-water bath immediately after treatments until further analysis.

\subsection{Microbial Analysis and Quality Assay}

\subsubsection{Microbial Enumeration}

The detection of viable total aerobic bacteria $(\mathrm{AB})$ and $\mathrm{Y} \& \mathrm{M}$ in clear red pitaya juice followed the method described by Liao et al. [17]. Samples were serially diluted at 10 times gradient with $0.85 \%$ sterile saline solution, and $1 \mathrm{~mL}$ of each dilution was spread on duplicate sterile petri dishes containing the Nutrient agar (Sinopharm Chemical Reagent Co., Ltd., Shanghai, China) and the Rose bengal agar (Sinopharm Chemical Reagent Co., Ltd., Shanghai, China), to enumerate residual cultivable AB and $Y \& M$ cells, respectively. The numbers of $A B$ and $Y \& M$ were counted after incubation at $37 \pm 1{ }^{\circ} \mathrm{C}$ for $48 \pm 2 \mathrm{~h}$, and at $28 \pm 1{ }^{\circ} \mathrm{C}$ for $72 \pm 2 \mathrm{~h}$. The limit of plate counting detection is $1 \mathrm{CFU} / \mathrm{mL}$.

\subsection{2. $\mathrm{pH}$ and Soluble Solid Content}

The $\mathrm{pH}$ of juice samples was detected using a $\mathrm{pH}$ meter (DELTA 320, Mettler-Toledo, Zurich, Switzerland) by immersing electrode in clear red pitaya juice samples at $25^{\circ} \mathrm{C}$. The SSC was measured using a pocket refractometer (PAL- $\alpha$, Atago, Tokyo, Japan) by dropping juice drops on the mirror face at $25^{\circ} \mathrm{C}$.

\subsubsection{Color Indexes}

Color indexes of juice samples were determined according to Liao et al. [14]. $\Delta E$ was calculated according to Equation (1):

$$
\Delta E=\sqrt{\left(L_{0}^{*}-L^{*}\right)^{2}+\left(a_{0}^{*}-a^{*}\right)^{2}+\left(b_{0}^{*}-b^{*}\right)^{2}}
$$

where $L_{0}{ }^{*}, a_{0}{ }^{*}$ and $b_{0}{ }^{*}$ represent the values of untreated sample, $L^{*}, a^{*}$ and $b^{*}$ represent the values of treated samples and during storage. 


\subsubsection{Betacyanins Content}

The content of betacyanins in the clear red pitaya juice was determined using a UVvisible spectrophotometer (Shimazu, UV mini-1240, Kyoto, Japan) according to the method of Marszałek et al. [18] with slight modifications. The content of betacyanins was calculated using the Equation (2):

$$
\text { Betacyanins content }(\mathrm{mg} / 100 \mathrm{~mL})=(A \times D F \times M W \times 100) /(\varepsilon \times L)
$$

where $A$ is absorbance at $538 \mathrm{~nm}, D F$ is dilution factor, and $L$ is path length $(=1 \mathrm{~cm})$, molecular weight $(M W)=550 \mathrm{~g} / \mathrm{mol}$, and molar extinction coefficient $(\varepsilon)=65000$.

\subsubsection{Enzymes Activity}

The polyphenol oxidase (PPO) activity was determined according to the method reported by Yi et al. [19] with slight modifications. Each $1 \mathrm{~mL}$ juice was mixed with $2 \mathrm{~mL}$ substrate containing $0.07 \mathrm{M}$ catechol and $0.2 \mathrm{M}$ phosphate buffer ( $\mathrm{pH}$ 6.5) as the enzymatic reaction solution.

The peroxidase (POD) activity was determined based on the method reported by Cao et al. [20] with slight modifications. Each $1 \mathrm{~mL}$ juice was diluted by $1-5$ times and then mixed with $2 \mathrm{~mL} 1.0 \%(v / v)$ guaiacol $(0.2 \mathrm{M}, \mathrm{pH} 6.5$ phosphate buffer) and $0.2 \mathrm{~mL} 1.5 \%$ hydrogen peroxide as the enzymatic reaction solution.

The absorbance at $420 \mathrm{~nm}$ and $470 \mathrm{~nm}$ of PPO and POD enzymatic reaction solutions were immediately recorded by a spectrophotometer (Ultrospec 7000, Biochrom LTD, Cambridge, UK) at intervals of $2 \mathrm{~s}$ for $4 \mathrm{~min}$. The specific activities of PPO and POD (Abs/min) were calculated according to the slopes of the linear portion of reaction curves, and the residual activities of enzymes were calculated according to Equation (3):

$$
\text { Residual activity of enzymes }(\%)=100 \times A_{\mathrm{t}} / A_{0}
$$

where $A_{\mathrm{t}}$ and $A_{0}$ represent the specific activities of treated and untreated samples.

\subsubsection{Browning Degree}

The browning degree (BD) of juice was determined using the method of Roig et al. [21]. Each $3 \mathrm{~mL}$ properly diluted sample was filtered through a $0.45 \mu \mathrm{m}$ polytetrafluoroethylene syringe filter (Wuxi Huabiao Scientific Instrument Co., Ltd., Wuxi, China). The absorbance of filtrate at $420 \mathrm{~nm}$ was measured at $25 \pm 1{ }^{\circ} \mathrm{C}$ and expressed as BD value.

\subsection{Statistical Analysis}

All data obtained in this study were expressed as mean value \pm standard deviation (SD). Analysis of variance (ANOVA) and Pearson correlation analysis were carried out with SPSS 23.0 (IBM Co., New York, NY, USA) using Duncan's test, and the significance level was $p=0.05$.

\section{Results and Discussion}

\subsection{Microbial Growth}

TS and thermal treatments effectively decreased the counts of $A B$ and $Y \& M$ in clear red pitaya juices to less than $10 \mathrm{CFU} / \mathrm{mL}$, while the US treatment had a negligible effect (Figure 2). Similarly, complete inactivation of total plate count (4.6-log) and enterobacteria (4.2-log) was obtained in green cactus pear juice that was treated by ultrasound waves at $60 \%$ amplitude level for $15-25 \mathrm{~min}$ with outlet temperature at $58-66^{\circ} \mathrm{C}$ and at $80 \%$ amplitude level at $71-76{ }^{\circ} \mathrm{C}$ [22]. Although both red pitaya and green cactus pear belong to cactus species, a higher initial $\mathrm{pH}$ (5.68 vs. 4.90) while a lower initial microbial level (e.g., 4.6-log vs. 4.9-log of total plate count) was found in the above-mentioned study as compared to ours, which may support the better inactivation effects under equal level of TS treatments. 


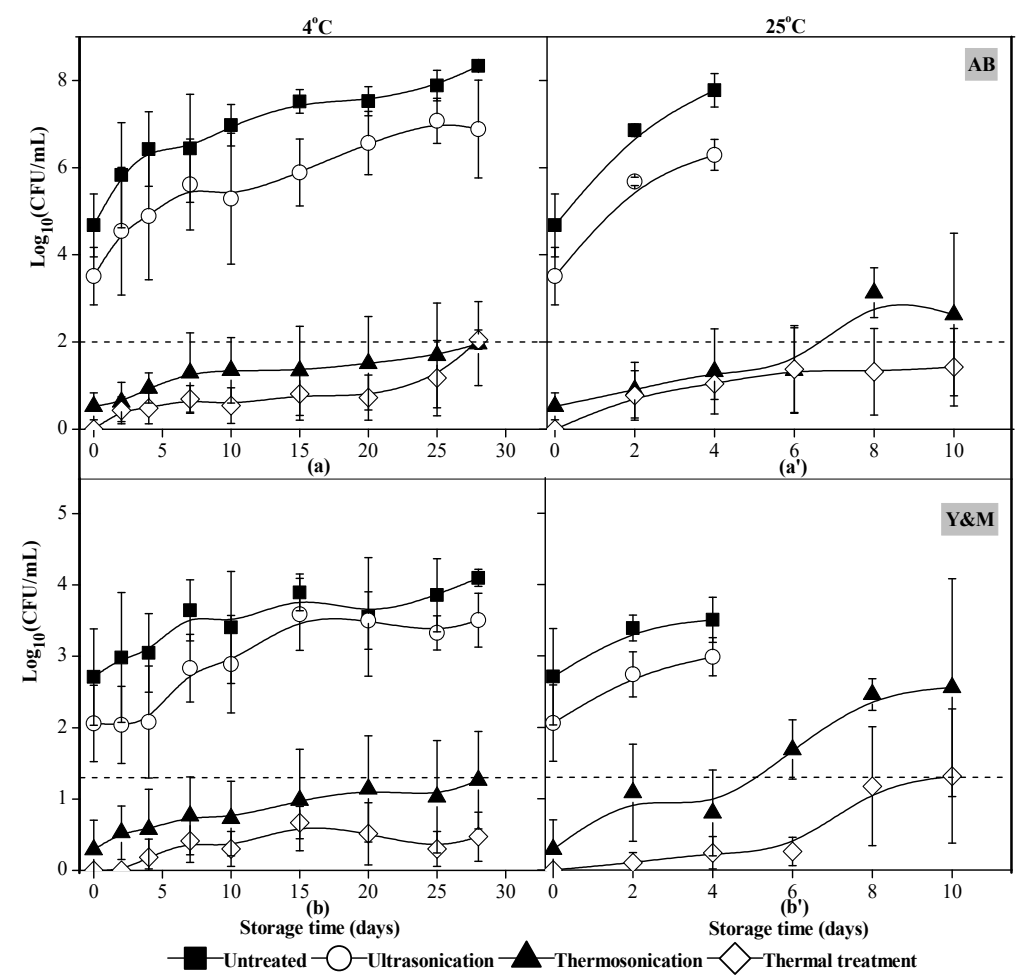

Figure 2. Changes of aerobic bacteria $\left(\mathbf{a}, \mathbf{a}^{\prime}\right)$, yeast and molds $\left(\mathbf{b}, \mathbf{b}^{\prime}\right)$ in red pitaya juices during storage at $4{ }^{\circ} \mathrm{C}$ and $25^{\circ} \mathrm{C}$, as subjected to thermosonication $\left(475 \mathrm{~W}, 56^{\circ} \mathrm{C}, 20 \mathrm{~min}\right)$, ultrasonication $(475 \mathrm{~W}$, $\left.10^{\circ} \mathrm{C}, 20 \mathrm{~min}\right)$, and thermal $\left(83^{\circ} \mathrm{C}, 1.5 \mathrm{~min}\right)$ treatments. Dotted lines were the acceptable limit defined by GB 7101-2015 [23].

During storage at $4{ }^{\circ} \mathrm{C}$ for 28 days and at $25^{\circ} \mathrm{C}$ for 10 days, TS- and thermal-treated clear red pitaya juices showed similar trends in $A B$ and $Y \& M$ growth, which was much slower as compared to the untreated and US-treated juices. The growth of $A B$ and $Y \& M$ in both TS- and thermal-treated juices were mainly due to existing few residual microorganisms. Similar increase trends in naturally occurring microorganisms in fruit and vegetable juices during storage were reported as subjected to TS and thermal processing $[12,13,24]$. For instance, the microbial counts in carrot juice reduced under the detection limit $(<1 \mathrm{CFU} / \mathrm{mL})$ after sonicated at $58^{\circ} \mathrm{C}$ for $10 \mathrm{~min}$, but the numbers of mesophiles and Y\&M increased to 3.1-log and 4.56-log during storage at $4{ }^{\circ} \mathrm{C}$ on day 20 [12]. It should be noticed that the $\mathrm{pH}$ value of carrot juice was 6.80 in the above-mentioned study, which provided a reasonable environment for microbial growth in theory. The total mesophilic bacteria and total psychrophilic bacteria in strawberry juice that heated at $90{ }^{\circ} \mathrm{C}$ for $60 \mathrm{~s}$ and then stored at $5{ }^{\circ} \mathrm{C}$ for 10 days increased to 3.20-log and 3.44-log, respectively, but Y\&M did not grow [24]. Several non-thermal technologies had been applied to pitaya juice processing. No growth of inoculated Saccharomyces cerevisiae in pitaya (Stenocereus pruinosus) juice that treated by $\mathrm{HHP}$ at $400-600 \mathrm{MPa}$ for 12-16 min and during storage at $4 \pm 1{ }^{\circ} \mathrm{C}$ up to 15 days was reported [8]. Both Listeria innocua and S. cerevisiae populations in pitaya (Stenocereus pruinosus) juice even decreased to non-detectable levels at 10 days of storage, treated by combining exposure to $\mathrm{O}_{3}$ for $7 \mathrm{~min}$ and followed by HHP at $316 \mathrm{MPa}$ for $5 \mathrm{~min}$ [4]. Besides that, the aerobic mesophiles and $Y \& M$ in pitaya juice remained at non-detectable levels as treated by $\mathrm{O}_{3}$ for $7 \mathrm{~min}$ and followed by HHP at $316 \mathrm{MPa}$ for $5 \mathrm{~min}$, and then stored at $5 \pm 2{ }^{\circ} \mathrm{C}$ for 30 days, but the number of $Y \& M$ abruptly accelerated to 3.37-log on day 35 [4]. These results suggested that a single inoculated strain in pitaya juice would be inactivated more easily than natural microbiota due to the possible presence of resistant strains. Therefore, high levels of TS treatments would be required to eliminate the resistant ones in clear pitaya juice to ensure microbial safety during storage. 
Growth of both $\mathrm{AB}$ and $\mathrm{Y} \& \mathrm{M}$ at $25^{\circ} \mathrm{C}$ were faster than that stored at $4{ }^{\circ} \mathrm{C}$, in all cases. Higher counts of $\mathrm{AB}$ and $\mathrm{Y} \& \mathrm{M}$ in untreated and US-treated samples were observed, which led to a fast and obvious increase in the natural microbiota during storage. Therefore, the untreated and US-treated juices showed signs of decay with off-odor after 4 days of storage at $25^{\circ} \mathrm{C}$. These samples were discarded for microbial and chemical analyses once visible signs of decay were observed. The results suggested that TS-treated sample was suitable for consumption after storage at $4{ }^{\circ} \mathrm{C}$ for 28 days, as it met the safety standards $(<100 \mathrm{CFU} / \mathrm{mL})$ of microbial counts [23].

\subsection{SSC, $p H$ and Color}

The SSC and $\mathrm{pH}$ values of clear red pitaya juice did not change significantly after treatment by TS $(p>0.05)$, as showed in Figure 3. The results were consistent with previous researches [15]. For instance, similar decrease in $\mathrm{pH}$ values of carrot, cactus pear, and orange juice during storage were reported $[22,25]$. Similar variation trends of SSC and pH were observed in thermal-treated samples.
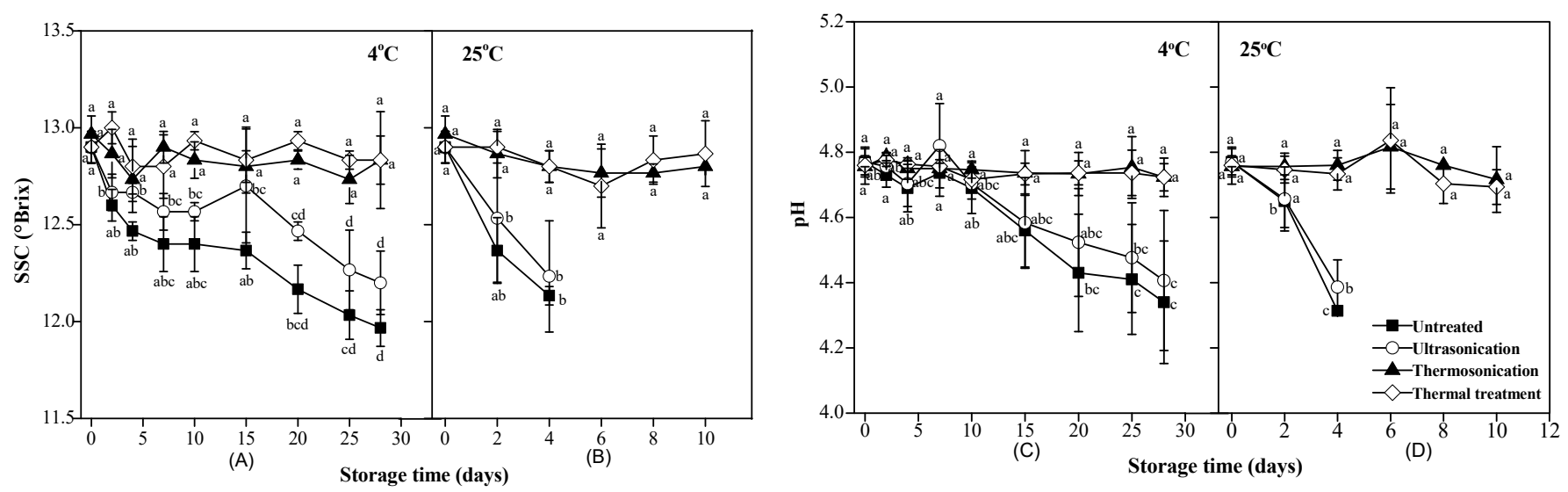

Figure 3. Variance of soluble solid content $\left((\mathbf{A})\right.$, samples stored at $4{ }^{\circ} \mathrm{C} ;(\mathbf{B})$, samples stored at $\left.25^{\circ} \mathrm{C}\right)$ and $\mathrm{pH}$ values $((\mathbf{C})$, samples stored at $4{ }^{\circ} \mathrm{C}$; (D), samples stored at $25^{\circ} \mathrm{C}$ ) in red pitaya juices during storage at $4{ }^{\circ} \mathrm{C}$ and $25^{\circ} \mathrm{C}$, as subjected to thermosonication $\left(475 \mathrm{~W}, 56^{\circ} \mathrm{C}, 20 \mathrm{~min}\right)$, ultrasonication $\left(475 \mathrm{~W}, 10^{\circ} \mathrm{C}, 20 \mathrm{~min}\right)$, and thermal $\left(83^{\circ} \mathrm{C}, 1.5 \mathrm{~min}\right)$ treatments, a, $\mathrm{b}, \mathrm{c}, \mathrm{d}$ means significant difference of SSC or $\mathrm{pH}$ values with respect to storage time $(p<0.05)$.

However, the SSC and $\mathrm{pH}$ values of untreated and US-treated samples reduced similarly and significantly $(p<0.05)$. The SSC values reduced to $11.97-12.2^{\circ}$ Brix and $12.13-12.23$ ${ }^{\circ}$ Brix after storage for 28 days at $4{ }^{\circ} \mathrm{C}$ and 10 days at $25^{\circ} \mathrm{C}$, respectively. Further analysis revealed a high correlation between the changes in SSC and $\mathrm{pH}$ values of untreated and US-treated samples during storage, with a great linear correlation coefficient $\left(R^{2}\right.$ adj $\left.=0.98\right)$. Like the variation of the microbial counts in clear red pitaya juice, slower changes in SSC and $\mathrm{pH}$ values were observed at a lower storage temperature. This phenomenon was considered relating to the metabolism of natural microbiota in untreated and US-treated clear red pitaya juice. It had been reported that acidity increases in juices when microorganisms use sugars as nutrients to produce organic acid, thus increasing acid concentration [26,27]. Soluble sugars, including glucose $(75 \mathrm{mg} / \mathrm{mL})$ and fructose $(22 \mathrm{mg} / \mathrm{mL})$, make up the majority of SSC in clear red pitaya juice [14]. They provide adequate carbon sources for lots of microorganisms. Similarly, it has been reported that the microbes metabolized sugar to produce organic acids, which leads to a decrease in $\mathrm{pH}$ and total sugars levels in orange juice [13]. Different results have been reported in processing carrot juice with TS; the $\mathrm{pH}$ value of carrot juice treated by TS at $58{ }^{\circ} \mathrm{C}$ presented a significant reduction after 20 days of storage $(p<0.05)$, although the sample did not show obvious spoilage [12]. They explained that the changes in $\mathrm{pH}$ after sonication were related to the generation of new chemical compounds and enzymatic changes in the media. 
The color indices of clear red pitaya juices during storage are shown in Figure 4. The $L^{*}, a^{*}$ and $b^{*}$ values of untreated juice were $30.78,20.36$, and 3.51, respectively. As subjected to US, TS, and thermal treatments, these color indices decreased, and the $\Delta E$ values were $1.08,3.59$, and 4.63 , respectively. TS treatment induced decrease in $L^{*}$ value, that is related to the changes of $a^{*}$ and $b^{*}$ values, and also to the browning substances generated from the Maillard reaction [14]. The decomposition of betacyanins directly resulted in the reduction in $a^{*}$ value. It might be explained as such: The nature of direct reaction of ultrasonic waves and lights with free radicals or secondary oxidants led to decomposition of betacyanins during storage in transparent glass bottles [28]. In addition, microbial metabolism generates substances like acid, alcohol, and gas might interfere with the stability of betacyanins and the color appearance of juice. Similar change of color indices of TS-treated juices during storage has been reported $[13,25]$. For instance, the $L^{*}, a^{*}$ and $b^{*}$ values of TS-treated $\left(56^{\circ} \mathrm{C}\right.$ for $6 \mathrm{~min}$ or $60^{\circ} \mathrm{C}$ for $5 \mathrm{~min}$ ) carrot juice decreased during storage at $4{ }^{\circ} \mathrm{C}$ for 21 days [25]. With regard to pitaya juice processing, a combination of $\mathrm{O}_{3}$ and $\mathrm{HHP}$ at $316 \mathrm{MPa}$ for $5 \mathrm{~min}$ caused reduction in $L^{*}$ value and its chroma, which was accelerated during the 30 days storage and eventually resulted in $\Delta E$ of 3.8 units [4]. According to our previous study, a $\Delta E$ of 5.0 units is a visible color difference threshold for clear red pitaya juice [14]. Invisible color change of TS-treated clear red pitaya juice was retained for 10 days at $4{ }^{\circ} \mathrm{C}$, which was longer than thermal-treated samples for 2 days (Figure 4). The results indicated a better color retention ability through TS than thermal treatment.
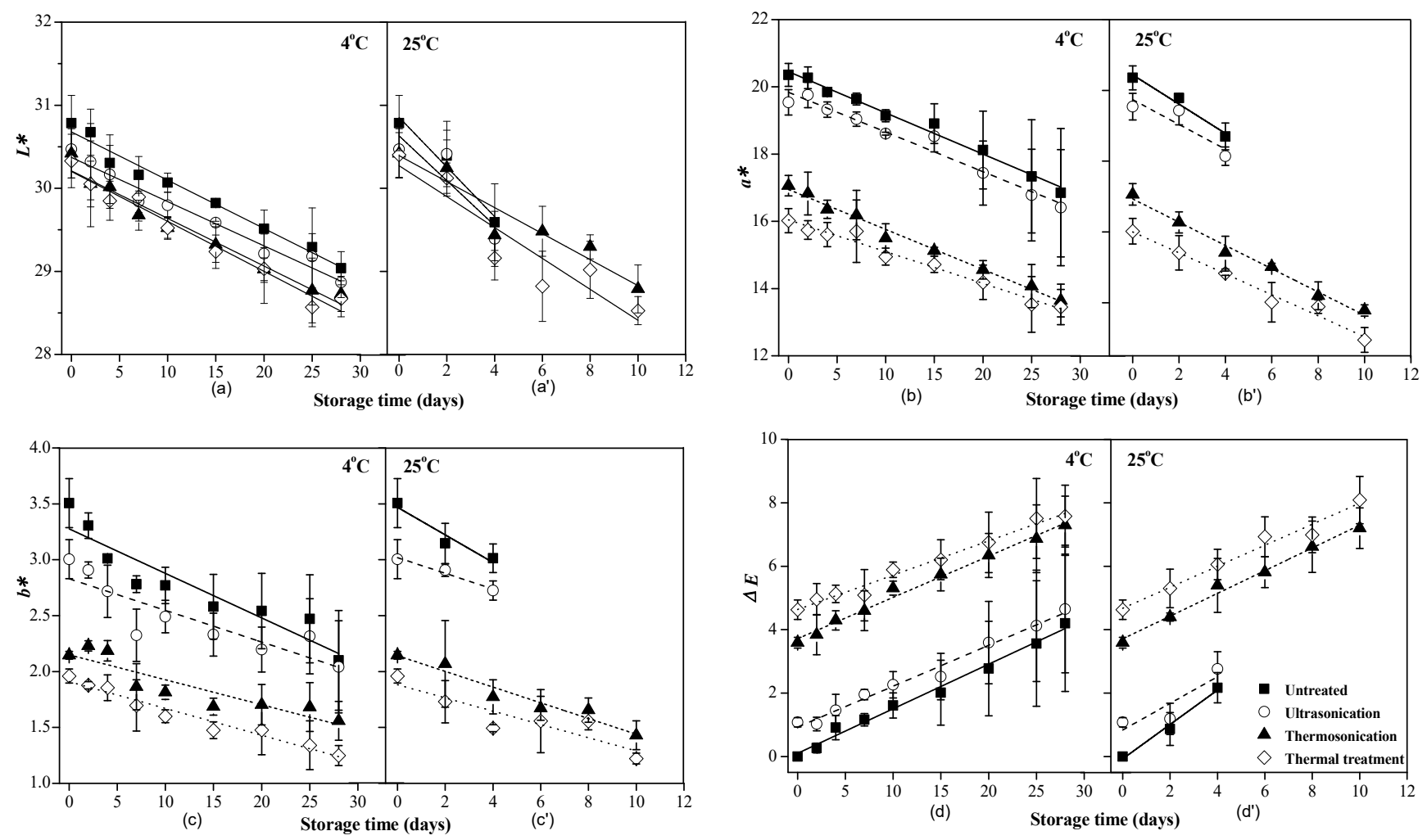

Figure 4. Variance in color of red pitaya juices during storage at $4{ }^{\circ} \mathrm{C}$ and $25{ }^{\circ} \mathrm{C}$, as subjected to thermosonication (475 $\mathrm{W}$, $\left.56{ }^{\circ} \mathrm{C}, 20 \mathrm{~min}\right)$, ultrasonication $\left(475 \mathrm{~W}, 10{ }^{\circ} \mathrm{C}, 20 \mathrm{~min}\right)$, and thermal $\left(83^{\circ} \mathrm{C}, 1.5 \mathrm{~min}\right)$ treatments. (a,a') Description of $L^{*}$ values during storage; $\left(\mathbf{b}, \mathbf{b}^{\prime}\right)$ Description of $a^{*}$ values during storage; (c, $\left.\mathbf{c}^{\prime}\right)$ Description of $b^{*}$ values during storage; $\left(\mathbf{d}, \mathbf{d}^{\prime}\right)$ Description of $\Delta E$ values during storage. Dotted lines are fitting curves with the linear model.

\subsection{Betacyanins Content}

The initial content of betacyanins in clear red pitaya juice was $14.49 \mathrm{mg} / 100 \mathrm{~mL}$; it decreased to $13.09-13.61 \mathrm{mg} / 100 \mathrm{~mL}$ after being treated by TS and thermal processing $(p<0.05)$, as shown in Figure 5. Under the storage conditions of $4{ }^{\circ} \mathrm{C}$ and $25^{\circ} \mathrm{C}$, the 
betacyanins content decreased linearly with the storage time, indicating loss in betacyanins during storage. The variation in betacyanins content at $25^{\circ} \mathrm{C}$ was $3.3-5.3$ times higher than that at $4{ }^{\circ} \mathrm{C}$ (based on the $k$ values of the linear fitted line), indicating a faster decomposition rate of betacyanins when stored at higher temperature. At the end of the storage at $4{ }^{\circ} \mathrm{C}$, $83.0 \%$ betacyanins were retained in TS-treated samples.

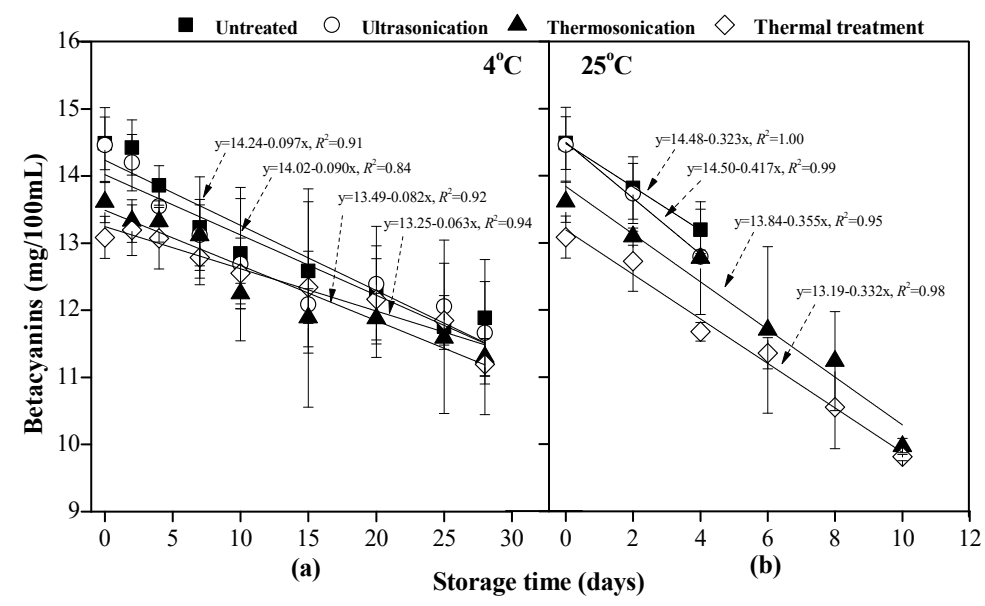

Figure 5. Change of the contents of betacyanins in red pitaya juices during storage at $4{ }^{\circ} \mathrm{C}$ (a) and $25^{\circ} \mathrm{C}(\mathbf{b})$, as subjected to thermosonication $\left(475 \mathrm{~W}, 56^{\circ} \mathrm{C}, 20 \mathrm{~min}\right)$, ultrasonication $\left(475 \mathrm{~W}, 10^{\circ} \mathrm{C}\right.$, $20 \mathrm{~min})$, and thermal $\left(83^{\circ} \mathrm{C}, 1.5 \mathrm{~min}\right)$ treatments. Dotted lines are fitting curves with the linear model.

Betacyanins undergo C15-isomerization, deglycosylation, dehydrogenation, hydrolysis, and decarboxylation during processing [29], leading to changes in the color of resulting food products. With regard to TS processing, the degradation and isomerization of betanin and phyllocactin are involved in the decomposition of betacyanins primarily [14]. In this study, significant decomposition of betacyanins in all samples were observed during storage $(p<0.05)$, which was slower at $4{ }^{\circ} \mathrm{C}$ than $25^{\circ} \mathrm{C}$. Similarly, after 8 -week storage, the amount of betacyanins in red pitaya juice at $4{ }^{\circ} \mathrm{C}$ was more than twice of it at $25^{\circ} \mathrm{C}$ [30]. According to observed results, automatic degradation of betacyanins occurred during storage in the present of lights, and this reaction was accelerated at a higher temperature. According to [3], partial regeneration of betanin occurs after short-term heating, though this phenomenon did not present in this study. In the present study, partial regeneration of betacyanins in the thermal-treated sample during storage might exist, as the lowest content of betacyanins presented in the thermal-treated sample. However, its retention rate $(85.6 \%$ at $4{ }^{\circ} \mathrm{C}$, as compared to that on day 0 ) was the highest one among all cases, suggesting that retained betacyanins in the thermally treated pitaya juices had a relatively high stability. To the best of our knowledge, it is the first time to report the decomposition dynamics of betacyanins in red pitaya juice after treatment by TS processing during storage. Future study can investigate its decomposition pathway during storage in order to minimize color decay of juices.

\subsection{PPO and POD Activities}

Endogenous enzymes such as PPO and POD are generally considered to ultimately lead to formation of dark brown polymers with quinoan properties, resulting in browning of fruit and vegetable products. Several studies have reported that TS inactivates PPO and POD [9,31]. For example, $93.85 \%$ PPO and 91\% POD in apple juice are inactivated by TS at $525 \mathrm{~W}$ and $60^{\circ} \mathrm{C}$ within $10 \mathrm{~min}$ [9]. Besides that, enzymatic oxidation of betanidin and betanin by horseradish peroxidase were reported by Wybraniec and Michałowski [32]. Possible disturbance of betalain stability by degrading endogenous enzymes such as PPO and POD has been proposed by Khan [33]. Herein, the influence of endogenous PPO and POD residues on betacyanins and resulting color change of clear red pitaya juice should be considered. 
As compared with untreated samples, PPO (Figure 6) and POD (Figure 7) activities reduced drastically after exposure to TS and thermal treatments. There were $2.3 \%$ and $16.7 \%$ residual enzyme activities of PPO and POD retained in TS-treated juice sample, and that did not change significantly $(p>0.05)$ during storage at $4{ }^{\circ} \mathrm{C}$ and $25^{\circ} \mathrm{C}$ for 28 days and 10 days. With regard to US treatment, negligible inactivation of PPO $(99.33 \%$ residual activity) and $24.9 \%$ reduction in POD activity were observed. These results indicated heat sensitivity of PPO and inactivation of POD by sonication and/or heat. A synergistic effect between thermal process and ultrasonic waves in the form of TS facilitated and resulted in enzymes deactivation. Moreover, limited residual enzyme activities of TS-treated samples did not contribute to enzymatic browning of juice during the whole experimental period, nor influence betacaynins retention.

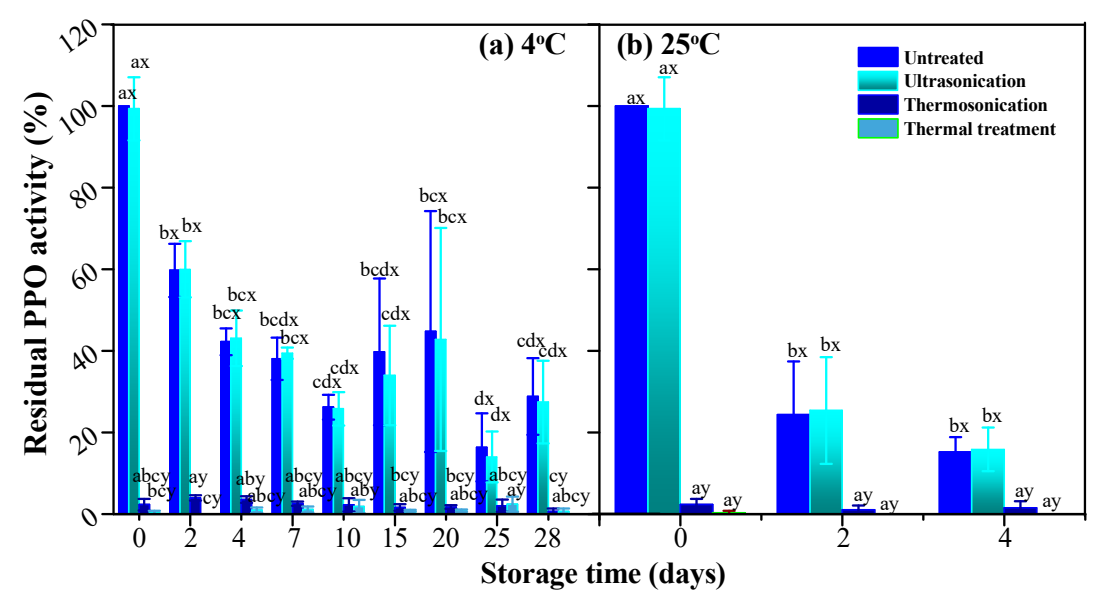

Figure 6. The residual activity of PPO in red pitaya juices during storage at $4{ }^{\circ} \mathrm{C}$ (a) and $25{ }^{\circ} \mathrm{C}(\mathbf{b})$, as subjected to thermosonication $\left(475 \mathrm{~W}, 56^{\circ} \mathrm{C}, 20 \mathrm{~min}\right)$, ultrasonication $\left(475 \mathrm{~W}, 10{ }^{\circ} \mathrm{C}, 20 \mathrm{~min}\right)$, and thermal $\left(83^{\circ} \mathrm{C}, 1.5 \mathrm{~min}\right)$ treatments. a, b, c, d means significant difference with respect to storage time $(p<0.05) ; \mathrm{x}, \mathrm{y}, \mathrm{z}, \mathrm{i}$ means significant difference with respect to various treatments $(p<0.05)$.

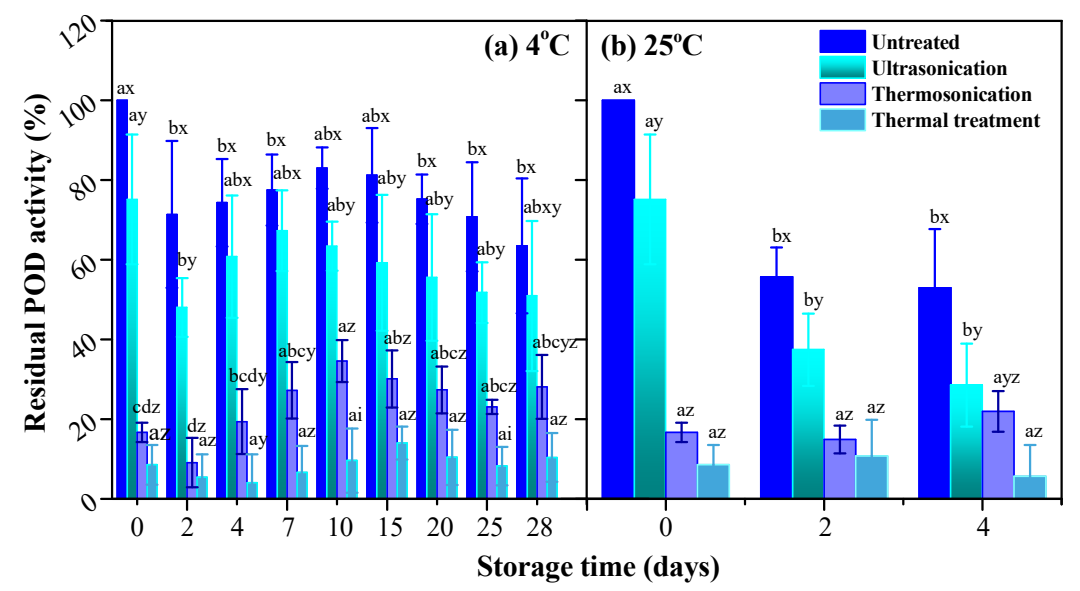

Figure 7. The residual activity of POD in red pitaya juices during storage at $4{ }^{\circ} \mathrm{C}(\mathbf{a})$ and $25^{\circ} \mathrm{C}(\mathbf{b})$, as subjected to thermosonication $\left(475 \mathrm{~W}, 56{ }^{\circ} \mathrm{C}, 20 \mathrm{~min}\right)$, ultrasonication $\left(475 \mathrm{~W}, 10^{\circ} \mathrm{C}, 20 \mathrm{~min}\right)$, and thermal $\left(83^{\circ} \mathrm{C}, 1.5 \mathrm{~min}\right)$ treatments. $\mathrm{a}, \mathrm{b}, \mathrm{c}, \mathrm{d}$ means significant difference with respect to storage time $(p<0.05) ; \mathrm{x}, \mathrm{y}, \mathrm{z}$, i means significant difference with respect to various treatments $(p<0.05)$.

\subsection{BD Value}

Change in $\mathrm{BD}$ values of clear red pitaya juice samples during storage are showed in Figure S1. A significant increase in BD values of red pitaya juices were observed as treated by TS and thermal processing $(p<0.05)$, with the order of thermal-processed juice $>$ TS-processed juice. The $\mathrm{BD}$ values did not vary during storage both at $4{ }^{\circ} \mathrm{C}$ or $25^{\circ} \mathrm{C}$ 
$(p>0.05)$. Non-enzymatic reactions between amino acids and carbohydrates caused by food processing persist during storage [34], but this reaction was not the main cause of the darkening of clear red pitaya juice.

\subsection{Pearson Correlation Analysis}

To analyze the multiple correlation of microbial and quality indices of TS- and thermaltreated clear red pitaya juices, a Pearson correlation analysis was conducted and is shown in Table 1. $\Delta E$ was significantly and negatively correlated with betacyanins content $(-0.91--0.98)$ in both processes, and betacyanins content was significantly positively correlated with $a^{*}(0.91-0.97)$. These indicated that the decomposition of betacyanins in clear red pitaya juice resulted in decrease of $a^{*}$ value and which led to the acceleration of color change (increase of $\Delta E$ ) ultimately during storage. Besides that, $\Delta E$ of TS-treated samples presented a positive correlation with microbial counts ( 0.96 for $\mathrm{AB} ; 0.85$ for $\mathrm{Y} \& \mathrm{M}$ ), and $\Delta E$ of thermal-treated samples presented positive but weaker correlation with microbial counts $(0.85$ for $A B ; 0.67$ for $Y \& M$ with $p<0.05)$. It indicated that, even as low as less than $10 \mathrm{CFU} / \mathrm{mL}$ residual native microbiota, the followed growth of these microbiota during storage influenced the quality of juice. Effective control of spoilage and pathogenic microbiota is a key aspect of microbial safety and food quality, especially during storage. Conversely, color or its change can serve as an indicator of microbial quality during storage of fruit and vegetable juices, which was consistent with a previous study [35]. The betacyanins contents of TS- and thermal-treated samples had a significant negative correlation with $\mathrm{AB}(-0.90--0.92)$ and $\mathrm{Y} \& \mathrm{M}(-0.61--0.83)$, indicating that effective control of microbiota would facilitate retention of betacyanins. Residual PPO and POD did not have significant correlation with the color properties of thermal-treated juices, even though they had significant correlation with $\Delta E$ and $a^{*}$ values of TS-treated samples. BD had a significant positive correlation with color indices $(>0.73)$ in both TS- and thermal-treated samples.

Table 1. Pearson correlation of microbial and quality parameters of thermosonication- (with gradient pink background) and thermal-treated clear red pitaya juice during storage.

\begin{tabular}{|c|c|c|c|c|c|c|c|c|c|c|c|c|}
\hline & $\Delta E$ & $L^{*}$ & $a^{*}$ & $b^{*}$ & Betacyanins & $\mathrm{pH}$ & SSC & PPO & POD & BD & $\mathbf{A B}$ & Y\&M \\
\hline$\Delta E$ & 1 & $-0.98^{* *}$ & $-1.00^{* *}$ & $-0.96 * *$ & $-0.91^{* *}$ & $-0.73^{* *}$ & -0.47 & 0.51 & 0.38 & $0.75^{* *}$ & $0.85^{* *}$ & $0.67^{*}$ \\
\hline$L^{*}$ & $-0.98 * *$ & 1 & $0.97 * *$ & $0.96 * *$ & 0.91 ** & $0.73^{* *}$ & 0.54 & -0.52 & -0.27 & $-0.73^{* *}$ & $-0.83^{* *}$ & $-0.71^{* *}$ \\
\hline$a^{*}$ & $-1.00 * *$ & $0.97^{* *}$ & 1 & $0.96 * *$ & $0.91 * *$ & $0.73^{* *}$ & 0.45 & -0.50 & -0.38 & $-0.75^{* *}$ & $-0.85 * *$ & -0.65 * \\
\hline$b^{*}$ & $-0.94 * *$ & $0.93 * *$ & 0.93 ** & 1 & $0.94^{* *}$ & $0.81 * *$ & 0.55 & -0.45 & -0.41 & $-0.78^{* *}$ & $-0.89 * *$ & $-0.77^{* *}$ \\
\hline Betacyanins & $-0.98 * *$ & $0.95^{* *}$ & $0.97^{* *}$ & $0.92 * *$ & 1 & $0.80 * *$ & 0.56 & -0.25 & -0.31 & $-0.67 *$ & $-0.90 * *$ & -0.61 * \\
\hline $\mathrm{pH}$ & $-0.75^{* *}$ & $0.68 *$ & $0.75^{* *}$ & $0.76^{* *}$ & $0.73^{* *}$ & 1 & 0.50 & -0.38 & -0.55 & -0.49 & $-0.64 *$ & $-0.66^{*}$ \\
\hline SSC & $-0.69 *$ & 0.71 * & $0.69 *$ & 0.53 & $0.65^{*}$ & 0.43 & 1 & -0.38 & -0.05 & -0.33 & -0.54 & $-0.58 *$ \\
\hline PPO & $-0.59 *$ & 0.45 & $0.60 *$ & $0.68 *$ & 0.57 & $0.65 *$ & 0.05 & 1 & 0.10 & 0.42 & 0.21 & 0.41 \\
\hline POD & $0.65^{*}$ & $-0.66^{*}$ & $-0.64^{*}$ & $-0.79 * *$ & $-0.69 *$ & $-0.76^{* *}$ & -0.45 & -0.43 & 1 & 0.16 & 0.23 & 0.55 \\
\hline BD & $0.77^{* *}$ & $-0.81 * *$ & $-0.77^{* *}$ & -0.80 ** & $-0.67 *$ & -0.43 & -0.53 & -0.46 & 0.44 & 1 & $0.73^{* *}$ & $0.61 *$ \\
\hline AB & $0.96^{* *}$ & $-0.96^{* *}$ & $-0.96^{* *}$ & $-0.94^{* *}$ & $-0.92^{* *}$ & $-0.76^{* *}$ & $-0.70 *$ & -0.56 & $0.74^{* *}$ & $0.83^{* *}$ & 1 & $0.59^{*}$ \\
\hline $\mathbf{Y} \& \mathbf{M}$ & $0.85 * *$ & $-0.79 * *$ & $-0.86 * *$ & $-0.79 * *$ & $-0.83 * *$ & $-0.65 *$ & -0.57 & $-0.68^{*}$ & 0.49 & $0.69 *$ & $0.85^{* *}$ & 1 \\
\hline
\end{tabular}

* Significant at $5 \%(p<0.05),{ }^{* *}$ Significant at $1 \%(p<0.01)$.

\section{Conclusions}

Results of the present study demonstrated that TS can be used as an alternative technology of thermal pasteurization in red pitaya juice processing, especially for microbial safety and physico-chemical quality control. The quality and stability of TS-treated red pitaya juices was equal to that treated by short time thermal processing at $83^{\circ} \mathrm{C}$. Though slight growth of native microbiota in TS-treated juices was observed during storage for 28 days at $4{ }^{\circ} \mathrm{C}$, they were below the acceptable limits defined by GB 7101-2015. Enzymatic browning and non-enzymatic browning were not the main reasons of color decay during storage, while the decomposition of betacyanins and the metabolism of residual native microbiota contributed to color decay. Slight increases in temperature might be better in controlling native microbiota in juice processing using TS technology, which may be conducive to food safety and quality control during storage. In that case, a shorter treatment 
time could be used to facilitate industrial application of TS. Further research can study the optimal treatment conditions for pilot or scaled-up juice processing in the future.

Supplementary Materials: The following are available online at https:/ /www.mdpi.com/article/ 10.3390/foods10051041/s1, Figure S1: The change of browning degree (A420 nm) of red pitaya juices during storage at $4{ }^{\circ} \mathrm{C}$ and $25{ }^{\circ} \mathrm{C}$, as subjected to ultrasonication $\left(475 \mathrm{~W}, 10{ }^{\circ} \mathrm{C}, 20 \mathrm{~min}\right)$, thermosonication $\left(475 \mathrm{~W}, 56^{\circ} \mathrm{C}, 20 \mathrm{~min}\right)$, and thermal treatment $\left(83^{\circ} \mathrm{C}, 1.5 \mathrm{~min}\right)$.

Author Contributions: Data curation, W.Z. and Y.A.; Formal analysis, Y.A.; Funding acquisition, H.L.; Methodology, F.F.; Validation, H.L.; Writing—original draft preparation, W.Z. and F.F.; Writingreview and editing, Y.A. and F.F. All authors have read and agreed to the published version of the manuscript.

Funding: This research was funded by projects of the National Key Research and Development Program of China (No. 2017YFD0400703-3, No. 2016YFD0400301).

Institutional Review Board Statement: Not applicable.

Informed Consent Statement: Not applicable.

Data Availability Statement: The data presented in this study are available on request from the corresponding author.

Conflicts of Interest: The authors declare that they have no known competing financialinterestsor personal relationships that could have appeared to influence the work reported in this paper.

\section{References}

1. Dolas, R.; Saravanan, C.; Kaur, B.P. Emergence and era of ultrasonic's in fruit juice preservation: A review. Ultrason. Sonochem. 2019, 57, 73-88. [CrossRef] [PubMed]

2. Cansino, N.C.; Carrera, G.P.; Rojas, Q.Z.; Olivares, L.D.; García, E.A.; Ramírez, E. Ultrasound processing on green cactus pear (Opuntia ficus Indica) juice:Physical, microbiological and antioxidant properties. J. Food Process. Technol. 2013, 4, 1-6.

3. Herbach, K.M.; Stintzing, F.C.; Carle, R. Betalain stability and degradation-structural and chromatic aspects. J. Food Sci. 2006, 71, R41-R50. [CrossRef]

4. García-Mateos, M.D.R.; Quiroz-González, B.; Corrales-García, J.; Ybarra-Moncada, M.C.; Leyva-Ruelas, G. Ozone-high hydrostatic pressure synergy for the stabilization of refrigerated pitaya (Stenocereus pruinosus) juice. Innov. Food Sci. Emerg. 2019, 56, 1-9.

5. Liaotrakoon, W.; Clercq, N.; Hoed, V.V.; Walle, D.V.D.; Lewille, B.; Dewettinck, K. Impact of thermal treatment on physicochemical, antioxidative and rheological properties of white-flesh and red-flesh dragon fruit (Hylocereus spp.) purees. Food Bioproc. Technol. 2013, 6, 416-430. [CrossRef]

6. Gengatharan, A.; Dykes, G.A.; Choo, W.S. The effect of $\mathrm{pH}$ treatment and refrigerated storage on natural colourant preparations (Betacyanins) from red pitahaya and their potential application in yoghurt. LWT-Food Sci. Technol. 2017, 80, 437-445. [CrossRef]

7. Halim, H.; Noranizan, M.; Sobhi, B.; Sew, C.C.; Karim, R.; Osman, A. Nonthermal pasteurization of pitaya (Hylocereus polyrhizus) juice using the hurdle concept. Int. Food Res. J. 2012, 19, 1457-1461.

8. Quiroz-González, B.; Rodríguez-Martínez, V.; García-Mateos, M.D.R.; Torres, J.A.; Welti-Chanes, J. High hydrostatic pressure inactivation and recovery study of Listeria innocua and Saccharomyces cerevisiae in pitaya (Stenocereus pruinosus) juice. Innov. Food Sci. Emerg. Technol. 2018, 50, 169-173. [CrossRef]

9. Abid, M.; Jabbar, S.; Hu, B.; Hashim, M.M.; Wu, T.; Lei, S.; Khan, M.A.; Zeng, X. Thermosonication as a potential quality enhancement technique of apple juice. Ultrason.Sonochem. 2014, 21, 984-990. [CrossRef] [PubMed]

10. Jabbar, S.; Abid, M.; Bing, H.; Hashim, M.M.; Lei, S.; Wu, T.; Zeng, X. Exploring the potential of thermosonication in carrot juice processing. J. Food Sci. Technol. 2015, 52, 7002-7013. [CrossRef]

11. Chitgar, M.F.; Aalam, M.; Kadkhodaee, R.; Maghsoudlou, Y.; Milani, E. Effect of thermosonication and thermal treatments on phytochemical stability of barberry juice copigmented with ferulic acid and licorice extract. Innov. Food Sci. Emerg. 2018, 50, 102-111. [CrossRef]

12. Martínez-Flores, H.E.; Garnica-Romo, M.G.; Bermúdez-Aguirre, D.; Pokhrel, P.R.; Barbosa-Cánovas, G.V. Physico-chemical parameters, bioactive compounds and microbial quality of thermo-sonicated carrot juice during storage. Food Chem. 2015, 172, 650-656. [CrossRef] [PubMed]

13. Wahia, H.; Zhou, C.; Mustapha, A.T.; Amanor-Atiemoh, R.; Mo, L.; Fakayode, O.A.; Ma, H. Storage effects on the quality quartet of orange juice submitted to moderate thermosonication: Predictive modeling and odor fingerprinting approach. Ultrason. Sonochem. 2020, 64, 1-17. [CrossRef] [PubMed]

14. Liao, H.; Zhu, W.; Zhong, K.; Liu, Y. Evaluation of colour stability of clear red pitaya juice treated by thermosonication. LWT-Food Sci. Technol. 2020, 121, 1-9. [CrossRef] 
15. Tiwari, B.K.; Patras, A.; Brunton, N.; Cullen, P.J.; O'Donnell, C.P. Effect of ultrasound processing on anthocyanins and color of red grape juice. Ultrason. Sonochem. 2010, 17, 598-604. [CrossRef] [PubMed]

16. Wibowo, S.; Vervoort, L.; Tomic, J.; Santiago, J.S.; Lemmens, L.; Panozzo, A.; Grauwet, T.; Hendrickx, M.; Loey, A.V. Colour and carotenoid changes of pasteurised orange juice during storage. Food Chem. 2015, 171, 330-340. [CrossRef]

17. Liao, H.; Jiang, L.; Cheng, Y.; Liao, X.; Zhang, R. Application of nisin-assisted thermosonication processing for preservation and quality retention of fresh apple juice. Ultrason. Sonochem. 2018, 42, 244-249. [CrossRef]

18. Marszałek, K.; Krzyżanowska, J.; Skapska, S. Kinetic modelling of polyphenol oxidase, peroxidase, pectin esterase, polygalacturonase, degradation of the main pigments and polyphenols in beetroot juice during high pressure carbon dioxide treatment. LWT-Food Sci. Technol. 2017, 85, 412-417. [CrossRef]

19. Yi, J.; Kebede, B.T.; Dang, D.N.H.; Buve, C.; Grauwet, T.; Loey, A.V.; Hu, X.; Hendrickx, M. Quality change during high pressure processing and thermal processing of cloudy apple juice. LWT-Food Sci. Technol. 2017, 75, 85-92. [CrossRef]

20. Cao, X.; Zhang, Y.; Zhang, F.; Wang, Y.; Yi, J.; Liao, X. Effects of high hydrostatic pressure on enzymes, phenolic compounds, anthocyanins, polymeric color and color of strawberry pulps. J. Sci. Food Agric. 2011, 91, 877-885. [CrossRef]

21. Roig, M.G.; Bello, J.F.; Rivera, Z.S.; Kennedy, J.F. Studies on the occurrence of non-enzymic browning during storage of citrus juice. Food Res. Int. 1999, 32, 609-619. [CrossRef]

22. Cruz-Cansino, N.D.S.; Ramírez-Moreno, E.; León-Rivera, J.E.; Delgado-Olivares, L.; Alanís-García, E.; Ariza-Ortega, J.A.; Manríquez-Torreset, J.D.J.; Jaramillo-Bustos, D.P. Shelf life, physicochemical, microbiological and antioxidant properties of purple cactus pear (Opuntia ficusindica) juice after thermoultrasound treatment. Ultrason. Sonochem. 2015, 27, 277-286. [CrossRef] [PubMed]

23. GB 7101-2015: National Food Safety Standard Beverage. Available online: http://www.nssi.org.cn/nssi/front/listpage.jsp (accessed on 13 November 2015).

24. Tomadoni, B.; Cassani, L.; Viacava, G.; Moreira, M.D.R.; Ponce, A. Effect of ultrasound and storage time on quality attributes of strawberry juice. J. Food Process Eng. 2017, 40, 1-8. [CrossRef]

25. Adiamo, O.Q.; Ghafoor, K.; Al-Juhaimi, F.; Mohamed Ahmed, I.A.; Babiker, E.E. Effects of thermosonication and orange byproducts extracts on quality attributes of carrot (Daucus carota) juice during storage. Int. J. Food. Sci. Technol. 2017, 52, 2115-2125. [CrossRef]

26. Rivas, A.; Rodrigo, D.; Martínez, A.; Barbosa-Cánovas, G.V.; Rodrigo, M. Effect of PEF and heat pasteurization on the physicalchemical characteristics of blended orange and carrot juice. LWT-Food Sci. Technol. 2006, 39, 1163-1170. [CrossRef]

27. Kwaw, E.; Tchabo, W.; Ma, Y.; Apaliya, M.T.; Sackey, A.S.; Mintah, B.K.; Farooq, M.; Ma, S. Effect of storage on quality attributes of lactic-acid-fermented mulberry juice subjected to combined pulsed light and ultrasonic pasteurization treatment. J. Food Meas. Charact. 2018, 12, 1763-1771. [CrossRef]

28. Taira, J.; Tsuchida, E.; Katoh, M.C.; Uehara, M.; Ogi, T. Antioxidant capacity of betacyanins as radical scavengers for peroxyl radical and nitric oxide. Food Chem. 2015, 166, 531-536. [CrossRef] [PubMed]

29. Rodriguez-Amaya, D.B. Update on natural food pigments-A mini-review on carotenoids, anthocyanins, and betalains. Food Res. Int. 2019, 124, 200-205. [CrossRef] [PubMed]

30. Siow, L.F.; Wong, Y.M. Effect of juice concentration on storage stability, betacyanin degradation kinetics, and sensory acceptance of red-fleshed dragon fruit (Hylocereus polyrhizus) juice. Int. J. Food Prop. 2017, 20, 623-632. [CrossRef]

31. Bot, F.; Calligaris, S.; Cortella, G.; Nocera, F.; Peressini, D.; Anese, M. Effect of high pressure homogenization and high power ultrasound on some physical properties of tomato juices with different concentration levels. J. Food Eng. 2018, 221, 70-76. [CrossRef]

32. Wybraniec, S.; Michałowski, T. New pathways of betanidin and betanin enzymatic oxidation. J. Agric. Food Chem. 2011, 59, 9612-9622. [CrossRef] [PubMed]

33. Khan, I.M. Stabilization of betalains: A review. Food Chem. 2016, 197, 1280-1285. [CrossRef] [PubMed]

34. Mendel, F. Food browning and its prevention: An overview. J. Agric. Food Chem. 1996, 44, 631-653.

35. Herceg, Z.; Lelas, V.; Jambrak, A.R.; Vukušić, T.; Levaj, B. Influence of thermo-sonication on microbiological safety, color and anthocyanins content of strawberry juice. J. Hyg. Eng. Des. 2013, 4, $26-37$. 